JFTH

Vol. 16, Issue 2 (2019)

ISSN: 2314-7024

JFTH

E-ISSN: 2682-2180

\title{
Representation of the Victory Procession in the Ancient Egyptian Art till the End of the New Kingdom
}

\author{
Gamal El-Din Abdel Razeq \\ Professor of Ancient Egyptian Language - Tourist Guiding Department \\ Faculty of Tourism and Hotels, Alexandria
}

\section{Dalia Yehia Abustet}

Associate professor of Egyptology - Tourist Guiding Department

Faculty of Tourism and Hotels, Alexandria

\section{Dalia Mohamed Soliman}

Researcher, Tourist Guiding Department

Faculty of Tourism and Hotels, Alexandria University

\section{Abstract}

Ancient Egyptian kings celebrated their military victories as early as the Old Kingdom. This was especially expressed in the art during the New Kingdom. The return of the victorious king from a war, a military battle, or an expedition was a very important theme in the wall scenes inside the ancient Egyptian temples. The research displays the earliest evidence of the victory procession in ancient Egypt, in addition to some scenes from the Early Dynastic Period till the end of the New Kingdom. It also includes an analysis of people who shared in the victory procession, in addition to elements, funerary rites, and the route of the procession.

Keywords: Victory, Procession, Military, Art, War, Triumph, Campaign.

\section{Introduction}

Kings of Egypt were keen on celebrating their victories by organizing great victory processions to reflect their power and strength in political and religious context. The first representation of a victory procession in the ancient Egyptian art dates back to the Early Dynastic period, it was represented on Narmer palette. The complete setting of the victory procession took place in the New Kingdom. The return of the victorious king from a war was very important in the representations inside the ancient Egyptian temples. The return from the foreign land laden with human captives was part of the returning triumphal march of the New Kingdom warrior kings. The king preceded by his army is first received by priests and high officials. Elite chariots 
advanced slowly with the various elite ranks. In the center were the royal guards, sons of the king, military scribes, and fan bearers. The city of Thebes was logically in festival, people are said to have come out to witness their leader's great success with floral bouquets. The representation of the victory procession expressed the ultimate gratitude to the gods who granted these victories, that's why after any victory; the king of Egypt was keen on presenting foreign captives and offerings to the gods inside their temples.

\section{Evidences of the Victory Procession from the Early Dynastic Period to the New Kingdom}

The researcher discusses here the earliest evidence of the victory procession in the ancient Egyptian art, in addition to other evidences till the end of the New Kingdoms.

\section{Early Dynastic Period (Narmer Palette)}

On the verso side of the palette: king Narmer is represented leading a victory procession.

The king is wearing the red crown of Lower Egypt and holding a mace in his left hand, while his right arm is bent over his chest, holding some kind of flail. ${ }^{1}$

He is walking in the conventional posture of the victorious pharaoh clubbing his prostrate foe and heading towards the captivated enemies. $^{2}$ The king is followed by his sandalbearer and preceded by smaller standard bearers carrying banners. ${ }^{3}$ The left-most standard represents some kind of animal skin, the second a dog and the next two a falcon. These standards might be the emblems of the royal house of Narmer, or of the regions that already belonged to his kingdom. ${ }^{4}$

The king here is inspecting the results of his victory. The emphasis on the king's bare feet on both obverse and reverse suggests that the ground he trod on was in some sense sacred, perhaps associated with a temple. It indicates that the king is walking towards the god's temple to present offerings and captives to the god who granted him this great victory.

To the far right there are two neat rows of ten enemies are shown, evidently the result of a successful campaign in an unknown region (the exact location is still open to debate). They are decapitated, prostrate on their backs, bound at the elbows, each has his head placed between his legs. Mysteriously, a boat is depicted over the bodies of the enemies including a harpoon- holding hawk, certainly to be identified as the god Horus, already tutelary deity of Egyptian kings. These signs are often interpreted as the name of the conquered region, which was the Mareotis region, the $7^{\text {th }}$ Lower-Egyptian province. ${ }^{6}$

The two signs in front of the probable name of the region, the wing of a door and a sparrow are thought to mean 'create' or 'found'. The entire group could thus be interpreted that on the occasion of the conquest of the Mareotis region, Narmer founded a new province, whose name was written by the ship, the harpoon and the falcon.

Other Egyptologists suggested that this scene represents the king's visit to the city of $\mathrm{P}$ to celebrate one of his military victories. ${ }^{7}$ Others suggested that this scene narrates Narmer's leadership of a southern confederation with processional banners representing various communities. ${ }^{8}$ This victory was in the north, a conquest that made Narmer the first ruler of the unified Egypt. ${ }^{9}$

Schulman suggests that the palette is representing the victory of Narmer over the Libyans. Gold Wasser said that they are Asiatics, and Newberry suggested that they are Bedouins. ${ }^{10}$ (Fig. 1) 


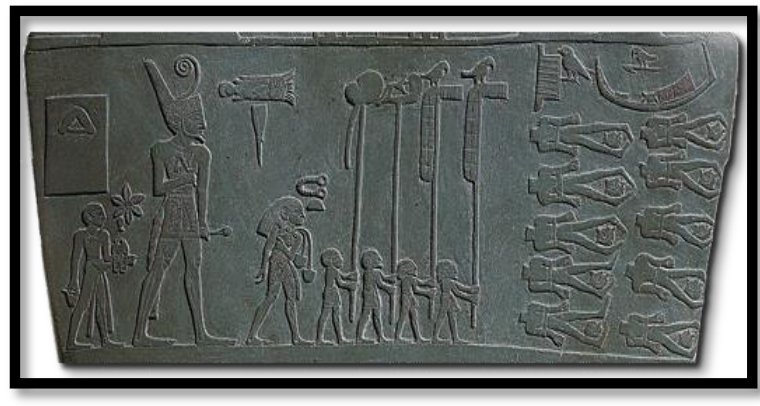

(Fig.1) Victory procession of king Narmer Narmer Palette - Hieraconpolis. Location: Preserved in the Egyptian museum. After: Teeter, E. (2011), before the pyramids "The Origins of Egyptian Civilization”, Fig. 16.4.

\section{Old Kingdom (Biography of Weni)}

Weni was a commander chief of the army in the $6^{\text {th }}$ dynasty. The second part from his biography clearly takes the form of a triumph song. It may have been composed specifically for inclusion in this biography, but it reads rather oddly in the context and certainly has the indication of an insertion from some other sources. It seems at least possible that it was composed for the triumphal return home of the victorious army and was sung by the troops in some sort of ritual context. This indicates that some victory processions took place in the Old Kingdom. ${ }^{11}$ (Fig. 2).

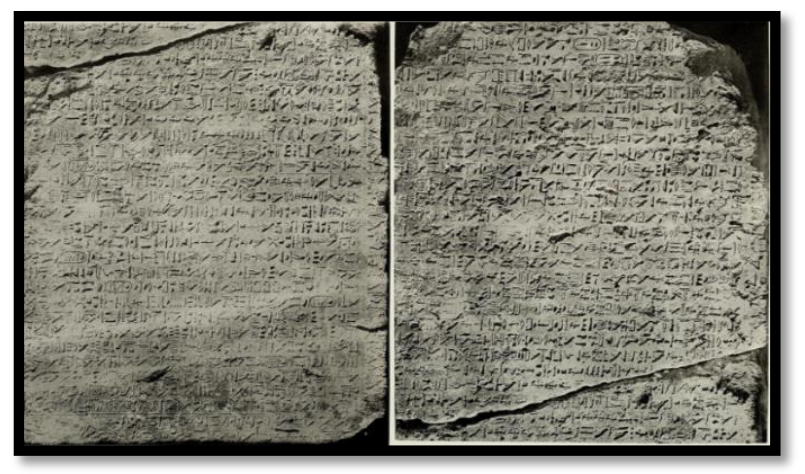

(Fig.2) Second Part from the Biography of Weni. After: Strudwick, N. (2005), Texts from the Pyramid Age, Atlanta: Society of Biblical Lit, P. 352.

\section{New Kingdom}

Although there are some early evidences for the victory procession since the early dynastic period, but the complete setting of the victory processions took place in the New Kingdom.

During the $18^{\text {th }}$ Dynasty, king Thuthmosis III has established at least three festivals of victory of five days. All these festivals included victory processions.

The Karnak stela of king Amenhotep II states that the booty obtained from his early Asiatic campaign was seen by everyone and strongly suggests a triumphal voyage through the country with the proceeds of victory very much on display to the acclamation of all people who could line the banks. ${ }^{12}$

At the end of the $18^{\text {th }}$ dynasty the king Horemheb, organized his victory procession after his battle in Palestine. ${ }^{13}$

The Karnak reliefs of king Seti I relating to his Asiatic victories describe a great victory procession of the king.

After his Kadesh campaign, Ramses II was presented captives to the god Amun within a great victory procession.

In all these instances a beautifully symmetrical scheme is evidently being applied: The Egyptians go forth to realize the will of Amun, and, when the king returns in victory, this is recognized by victory processions that include presentations of booty and prisoners to Amun who supported the campaign in the first place and granted the king his victory. ${ }^{14}$

\section{The Route of the Victory Procession}

When the victorious king returns to his capital after any successful campaign, he passes along a great processional route in triumph. The captives and a vast amount of booty were brought to the palace to be displayed before the king, who inspected them from the balcony (the window of appearance), Nobles and courtiers standing below and acclaiming their victorious sovereign. ${ }^{15}$ 
The procession begins from the king's palace to the god's temple where the king presented offerings to thank the god for giving him power and victory over his enemies, In addition to honoring the military officials by granting them houses, servants, cattle, slaves, ${ }^{16}$ gold, or medals. ${ }^{17}$

In the narrative account of Kamose's return to his capital Thebes after achieving a military victory over the Hyksos in Avaris, he reported that: (The river bank was excited) which indicate that the return voyage may have by water. Kamose then entered the Karnak temple and approached to the sanctuary, where he was granted the sickle- shaped sword of victory by the state god Amun. In other words the first major event after disembarkation seems to have been the necessity of returning to the exact location where the oracle of victory was given to Kamose by the god Amun. ${ }^{18}$

\section{Elements of the victory procession}

The victory procession was headed by the king, preceded by royal military chariots, followed by some military troops from different nationalities who shared in the military battles. In the center were the royal guards, sons of the king, the military scribes, and the fan bearers as in the victory processions of the king Ramses III at Medinet Habu temple. ${ }^{19}$

After the victory of Kamose over the Hyksos in Avaris, the procession was headed by chariots; at the end of the procession the captives of the war were represented. The king preceded by his army is first received by Priests, high officials, ${ }^{20}$ and the princes of upper and Lower Egypt. People are said to have come out to witness their leader's great success $^{21}$ wearing new clothes and holding floral bouquets. 22

In the account of Kamose it was son returning to father and thanking him for the military success, the homage to Amun was of primary importance. Elite chariots advanced slowly on the right and left of the Nile with the various elite ranks surrounding the core body of foot soldiers. Pharaoh remained on his flagship, the falcon ship with his intimate group of leaders and officials protecting him. ${ }^{23}$

IV. Musical instruments used in the victory procession

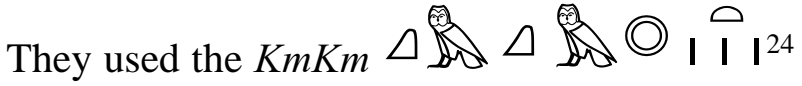
(a small drum), the sound was produced by a barrel shape. This must have been considered more satisfactory than that of a cylinder.

The trumpet ( $\check{s} n b)$ was represented on Medinet Habu temple walls. It was used to announce the arrival of the king to the public.

Professional musicians were participated in the victory procession, In addition to Egyptian and Nubian dancers. ${ }^{25}$

\section{Representation of the Victory Procession in the New Kingdom}

\section{During the Reign of the King Tutankhamoun $\left(18^{\text {th }}\right.$ dynasty $)$}

There were two military campaigns in the later years of Tutankhamoun, one against Asiatics and one against Nubians. The Talatat blocks recorded four episodes from those battles, in addition to the victory procession of the king Tutankhamoun.

The victory procession of the king shows the Egyptian king and soldiers returning to Egypt after their victory over the Nubians. Soldiers are wearing the tasseled helmets of the Asiatics defeated in the previous battle, and the soldiers from the Asiatic battle have spears threaded with enemy hands. The charioteers all walk alongside their plumed horses, clutching the reins, whilst accompanied by infantry, holding battle axes and open fans. ${ }^{26}$ (Fig.3) 


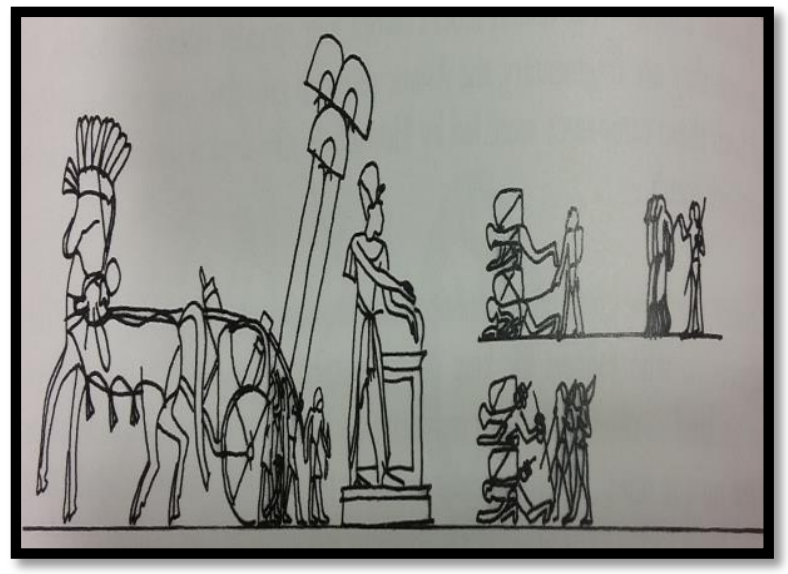

(Fig. 3) The victory procession of king

Tutankhamoun after his triumph over the Nubians. Location of the scene: Talatat blocks- Karnak. After: Booth, CH. (2009), Horemheb: The Forgotten pharaoh, Fig. 20.

\section{During the Reign of King Horemheb $\left(18^{\text {th }}\right.$ dynasty)}

King Horemheb built a rock- chapel for the god Amun- $\mathrm{Ra}$ at the western bank of Gebel el-silsila. The western wall of the chapel depicts one of the most noted reliefs of Horemheb, the king's victory procession after his triumph in Nubia. Horemheb is shown seated on a portable lion-chair which is carried by twelve soldiers wearing plumes of feathers. The king is preceded by a priest burning incense to drive away evil spirits from the way of the procession. At the front and back of the king are his fan-bearers, protecting pharaoh from the sun. His entourage includes rows of priests, soldiers, a trumpeter and several groups of captured prisoners. ${ }^{27}$ (Fig.4)

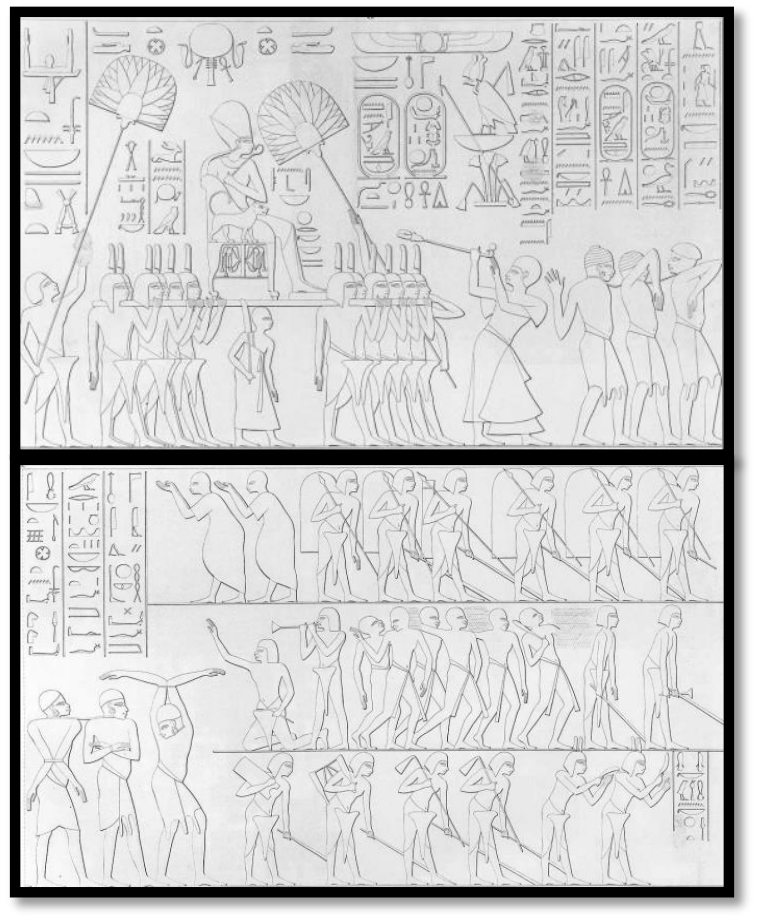

(Fig. 4) King Horemheb is sitting on a palanquin throne in his victory procession.

Location of the scene: Great chapel of Horemheb, Gebel el-Silsila, west wall.

After: Lorton, D. (1999), Born in Heaven, Made on Earth: The Theology of Cult Statues in Ancient Egypt, "The Making of the Cult Image in the Ancient near East", USA: Eisenbrauns, pl. 21 A-B.

\section{During the reign of king Ramses III $\left(20^{\text {th }}\right.$ dynasty)}

Scenes of the victory procession during the reign of the king Ramses III were represented on the first open court and the exterior walls of Medinet Habu temple.

The king is shown returning in victory after his triumph over Libyans and Syrians.

The king is shown in different episodes from his victory procession as follows:

The king is riding his chariot and welcomed by his priests with floral bouquets. High officials are pushing captives in front of the king's chariot. ${ }^{28}$ Scribes are registering the number of the enemies' hands in front of the king. ${ }^{29}$

The king is presenting captives and booties of the war to the Theban triad. ${ }^{30}$ 


\section{First Open Court -Northern Wall}

The first scene shows king Ramses III celebrating his victory over the Syrians in a victory procession. High officials are presenting the Syrian prisoners to the king. The hereditary prince, high employers, and courtiers are preceding the prisoners. Behind the king are the fan bearers and his guards. ${ }^{31}$ (Fig.5 )

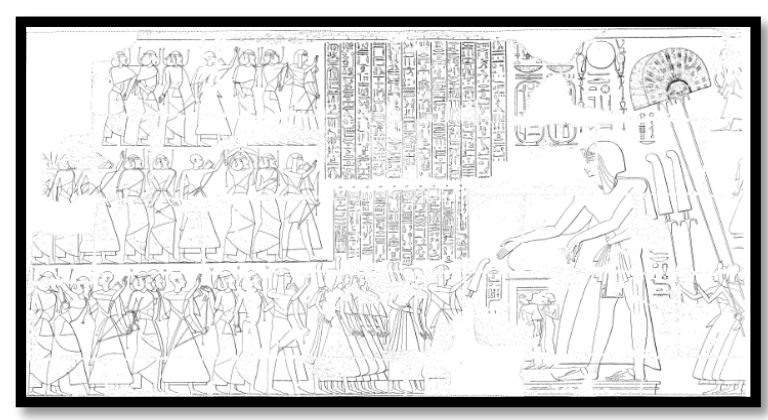

(Fig.5) Victory procession of king Ramses III after his victory over the Syrians.

Location of the scene: $1^{\text {st }}$ open court- North Wall Medinet Habu Temple.

After: Epigraphic Survey, Editors: Wilson, J. \& Allen, T. (1932), Medinet Habu, vol. II, later Historical Records of Ramses III, Chicago: Oriental Institute of the University of Chicago, pl. 96.

The second scene represents the king Ramses III in his chariot within a victory procession, leading in front of him three lines of prisoners. There are prophets and high officials welcoming the king and presenting to him bouqets of flowers to the far left side. ${ }^{32}$ (Fig. 6 )

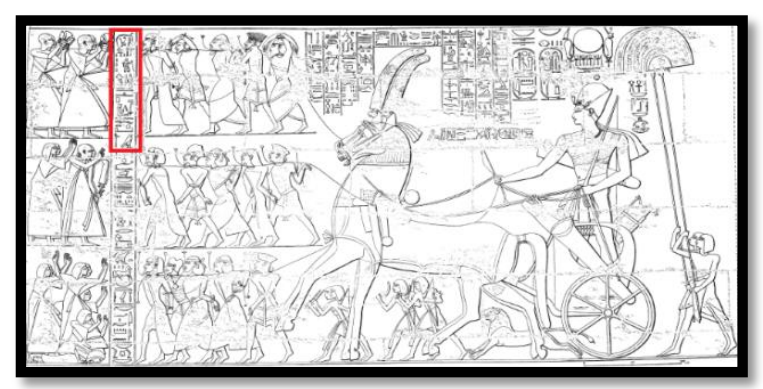

(Fig.6 ) Ramses III in a victory procession after his victory in Amor.

Location of the scene: $1^{\text {st }}$ open court - North wall Medinet Habu temple.

After: Epigraphic Survey, Editors: Wilson, J. \& Allen, T. (1932), Medinet Habu, vol. II, later Historical Records of Ramses III, pl. 98.
In front of the prophets and high officials is a text reads as follows:

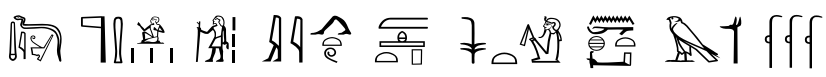

dd mdw in hmw ntr srw ${ }^{34}{ }^{3 i}{ }^{35} \mathrm{~m}$ htp nsw nht hr $n s w r n p w{ }^{36}$

\section{"Words spoken by the prophets and the officials: (welcome in peace, $O$ mighty king, the Horus: rich in years!)" 37}

\section{First Open Court -Southern Wall}

This wall shows a representation of the victory procession of king Ramesses III after his triumph in the second Libyan war. On the upper register, the king is riding his chariot with his horse trampling the enemies and his strong lion is running beside the chariot. Ramses III is preceded by four lines of his soldiers leading the procession before him. In the second sub register there is a trumpet player announcing the return of the triumphant king and the beginning of the victory procession. The king is followed by his fan bearers and his followers. On the lower register, another group of soldiers and priests are walking in the procession. ${ }^{38}$ (Fig. 7)

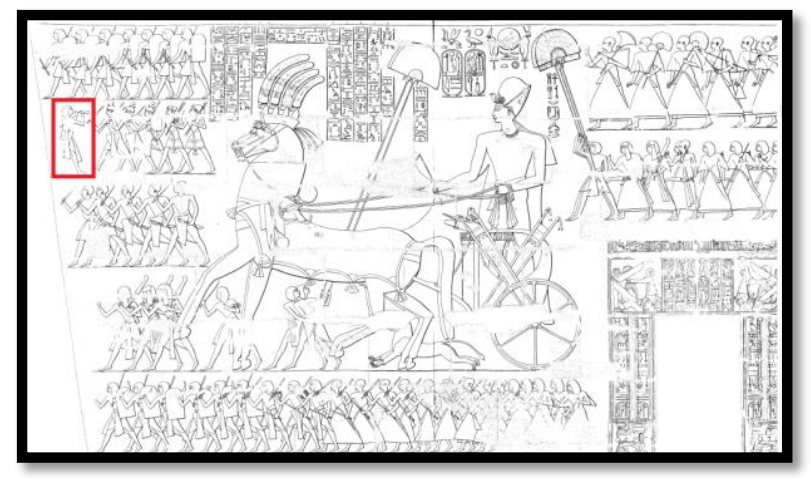

(Fig. 7) King Ramses III is riding his chariot in his victory procession after his triumph in the $2^{\text {nd }}$ libyan war. Location of the scene: $1^{\text {st }}$ open court- South wall - Medinet Habu temple.

After: Epigraphic Survey, Editors: Wilson, J. \& Allen, T. (1932), Medinet Habu, vol. II, later Historical Records of Ramses III, pl. 62. 


\section{First Open Court -Eastern Wall}

The hereditary prince and two ministers are presenting captives and booties to the king Ramses III after the second libyan war. Behind the king are two fan bearers, and before him his eldest son and two vizires. In the second register: there are scribes counting the number of the enemies's hands to the right and Egyptian soldiers to the left.$^{39}$ (Fig. 8)

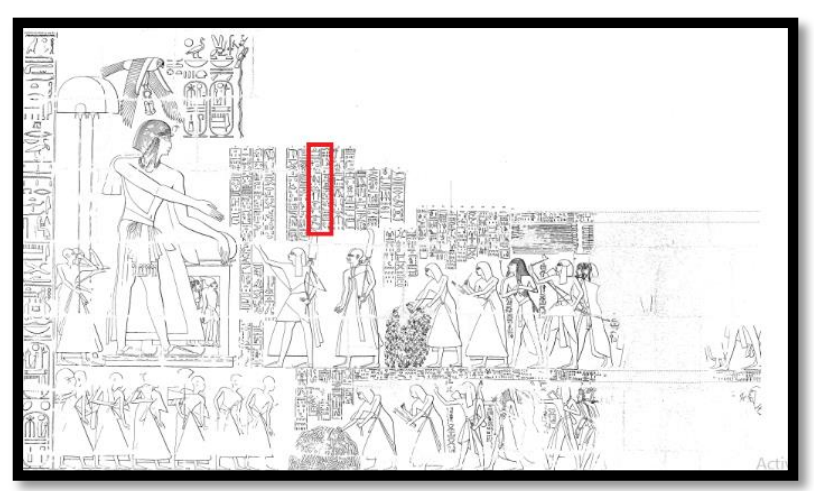

(Fig. 8) King Ramses III is receiving the booties of the war after the $2^{\text {nd }}$ Libyan war during the procession. Location of the scene: $1^{\text {st }}$ open court - East wall Medinet Habu temple.

After: Epigraphic Survey, Editors: Wilson, J. \& Allen, T. (1932), Medinet Habu, vol. II, later Historical Records of Ramses III, pl. 75 .

In line $7 \& 8$ above the court officials there is a text can be read as follows:

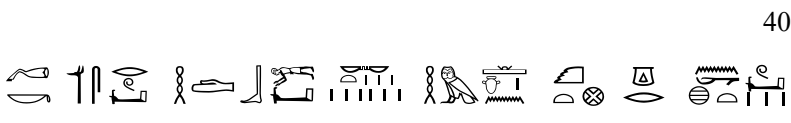

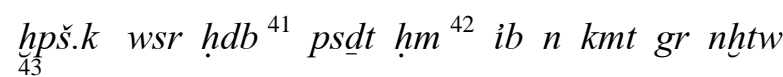

"Your arm is strong, overthrowing the nine bows. Glad is the heart of Egypt in the possession of victory" ${ }^{\prime 4}$

\section{The exterior walls of Medinet Habu temple}

\section{The Northern Wall}

The northern exterior wall depicts some episodes from the victory processions of the king Ramses III after his victory over Libyans and Syrians.

The first scene shows one episode from the victory procession of the king which represents the king returning in triumph from the second Libyan war. The king is riding his chariot with his lion running beside the chariot. In front of the king two lines of Libyan captives are depicted, while priests to the far right are welcoming the king and presenting floral bouquets to him. ${ }^{45}$ (Fig.9)

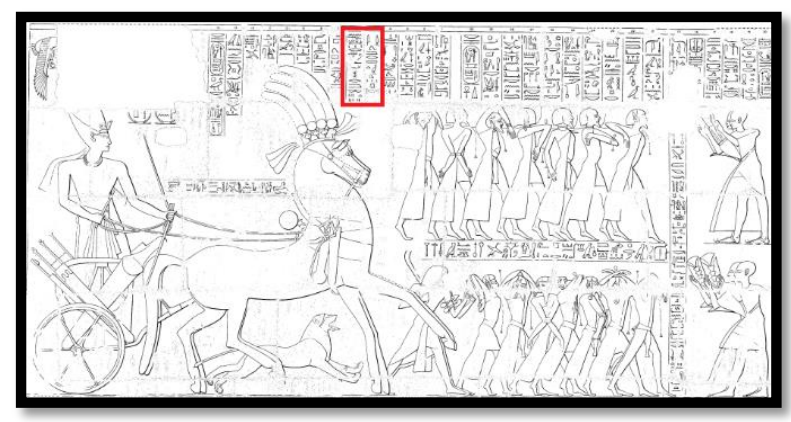

(Fig.9) The victory procession of king Ramses III after the $2^{\text {nd }}$ Libyan war.

Location of the scene: Exterior walls- North Wall Medinet Habu Temple.

After: Epigraphic Survey, Editors: Wilson, J. \& Allen, T. (1932), Medinet Habu, vol. II, later Historical Records of Ramses III, pl.77.

The $5^{\text {th }} \& 6^{\text {th }}$ lines of the text before the king can be read as follows:

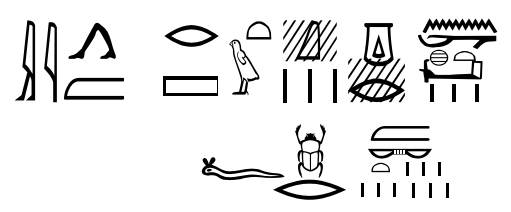

'Ti $m$ ršwt gr nhtw $r d w . f^{46}$ hpr m psdt

"Returning with joy in victory, when his (king Ramses III) success is achieved among the nine bows." 47

The second scene shows another episode from the victory procession of the king which represents the king after his success in a Libyan campaign. The hereditary prince, the supreme counter of the army, and the royal scribe are presenting three lines of Libyan 
prisoners to the king Ramses III. All prisoners are represented with their hands tied by ropes behind their backs, or behind their heads, of in front of their chests. The king is standing on one captive as a symbol of his victory and followed by two fan bearers. ${ }^{48}$ (Fig.10)

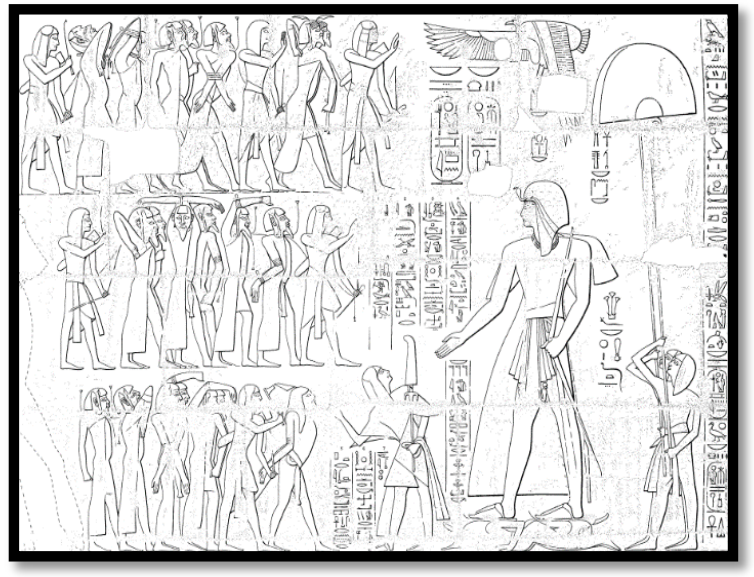

(Fig.10 ) Libyan prisoners being presented to king Ramses III in the victory procession.

Location of the scene: Exterior walls - North Wall Medinet Habu Temple.

After: Epigraphic Survey, Editors: Wilson, J. \& Allen, T. (1932), Medinet Habu, vol. II, later Historical Records of Ramses III, pl. 74.

The following scene shows another episode from the victory procession of the king Ramses III after his victory over the Syrians. The king is riding his chariot and leading in front of him two lines of Syrian prisoners. ${ }^{49}$ (Fig.11)

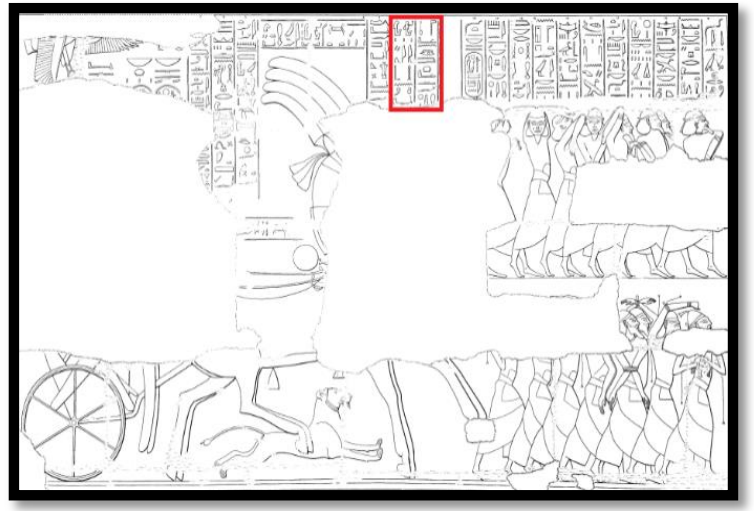

(Fig. 11) King Ramses III riding his chariot in his victory procession after his triumph over the Syrians. Location of the scene: Exterior walls - North Wall Medinet Habu Temple.

After: Epigraphic Survey, Editors: Wilson, J. \& Allen, T. (1932), Medinet Habu, vol. II, later Historical Records of Ramses III, pl. 92.
The $1^{\text {st }} \& 2^{\text {nd }}$ lines of the text above the king can be read as follows:

ๆ

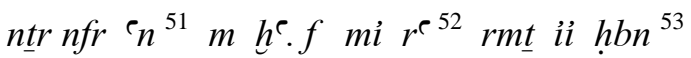

"The good god, beautiful when he appears like Ra (before the) people, returning when he has triumphed". ${ }^{54}$

The following scene shows the last episode of the victory procession. The king Ramses III presenting two lines of Syrian prisoners to god Amun and Khonsu. There are some vases of foreign design (booties of the war) in front of the king. ${ }^{55}$ (Fig.12)

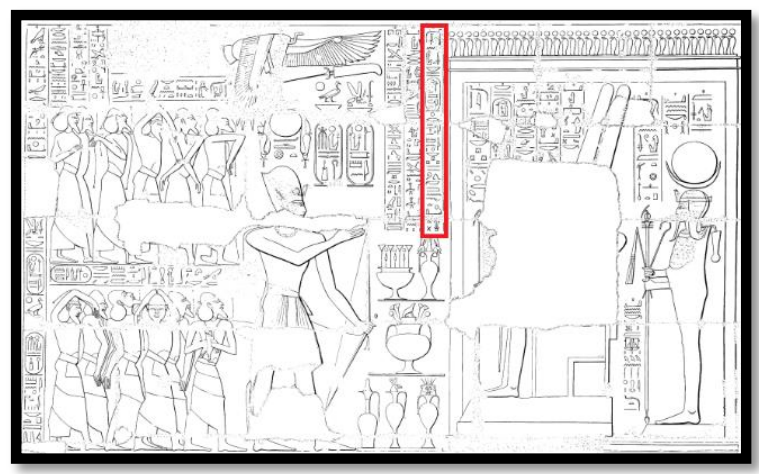

(Fig.12 ) King Ramses III presenting Syrian prisoners to god Amun and Khonsu.

Location of the scene: Exterior walls - North Wall Medinet Habu Temple.

After: Epigraphic Survey, Editors: Wilson, J. \& Allen, T. (1932), Medinet Habu, vol. II, later Historical Records of Ramses III, pl. 93.

The text written before the god Amun reads as follows:

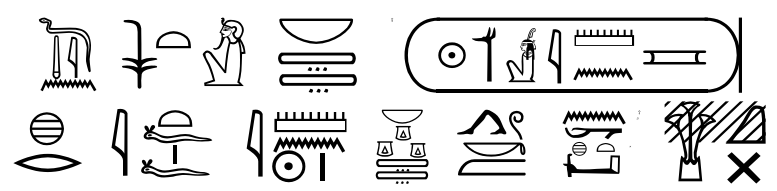

dd $m d w$ in $n s w$ nb t3wy wsr-m3et- $R^{e}-m r y-i m n$ hr it.f imn $R^{e} n b t 3 w y$ iw ${ }^{56} n h t h K^{57}$

"Word spoken by the king, the lord of the two lands: Usermare- Meriamon, in the presence of his father Amon- Re, lord of the thrones of the two lands : I'm come in victory, (for I have taken) captive." 58 


\section{Conclusion}

After discussing scenes and analyzing elements of the victory procession from the Early Dynastic period till the New Kingdom, it was figured out that:

The representation of the victory procession acted as a strict political warnings against the enemies of Egypt who became more dangerous especially during the New Kingdom.

There is no representation for the victory procession in any temple from the Middle Kingdom.

The best preserved scenes showing the victory procession belong to king Ramses III from his temple at Medinet Hebu.

Nubian, Libyan, Syrian, and foreign captives were represented in the victory procession. This is reflecting the strength of the Egyptian Empire especially during the New Kingdom.

The representation of the victory procession expressed the ultimate gratitude to the gods who granted these victories.

Egyptian women didn't participate in the victory procession.

The victory procession played a great role in increasing the enthusiasm of soldiery of the ancient Egyptians towards their country, and perpetuated this victory forever.

1 Emery, W. (1961), Archaic Egypt, England: Penguin Books, p. 43.

2 Lloyd, A. (2014), Ancient Egypt State and Society, UK: Oxford University Press, p. 133.

3 Schulman, A. (1964), Military Rank, Title, and Organization in the Egyptian New kingdom, Berlin: Verlag Bruno Hassling, p 69.

${ }^{4}$ Peck, W. (1979), Egyptian Drawings, London: Hames \& Hudson Ltd, p. 38.
5 Kinnaer, J. (2004), "What Is Really Known About Narmer Palette”, KMT (15), No.1, p. 54.

${ }^{6}$ Teeter, E. (2011), before the pyramids "The Origins of Egyptian Civilization", Chicago: The Oriental Institute in the University of Chicago, p.147.

${ }^{7}$ Bestock, L. (2018), Violence and Power in Ancient Egypt "Image and Ideology before the New Kingdom", Routledge Studies in Egyptology Series, New York: Taylor \& Francis Group, p. 64.

${ }^{8}$ Brier, B., \& Hobbs, H. (2008), Daily life of the Ancient Egyptians, $2^{\text {nd }}$ (ed.), London: Green Wood Publishing Group, p. 2:3

9 Millet, N. (1990), "The Narmer Mace head and Related Objects", ARCE (27), American Research Center in Egypt, p. 59.

${ }^{10}$ Serrano, A. (2002), Royal Festivals in the late Pre Dynastic Period and the First Dynasty, BAR International Series, Michigan: Archaeopress, p. 74, 83.

${ }^{11}$ Lloyd, A. (2014), Ancient Egypt State and Society, p. 133.

${ }^{12}$ Lloyd, A. (2014), Ancient Egypt State and Society, p. 134.

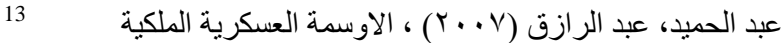

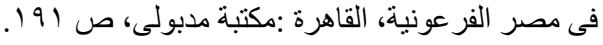

${ }^{14}$ Lloyd, A. (2014), Ancient Egypt State and Society, p. 134.

15 Blackman, A. (1923), Luxor and its Temples, UK: Billing and Sons Ltd, p.103.

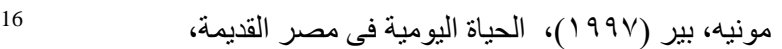

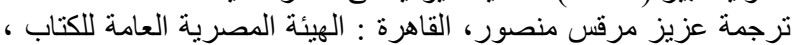

ص O

رانكه، هرمان (د.ت) ، مصر و الحياة المصرية في العصور 17 القديمة، ترجمة ومر اجعة: دم/ عبد المنعم ابو بكر \& \& محرم كمال، القاهرة: مطبعة مصر ،ص كمال م • 7.

${ }^{18}$ Gilbert, G. (2008), Ancient Egyptian Sea Power and the Origin of Maritime Forces, Australia: Sea Power Center, p. 42.

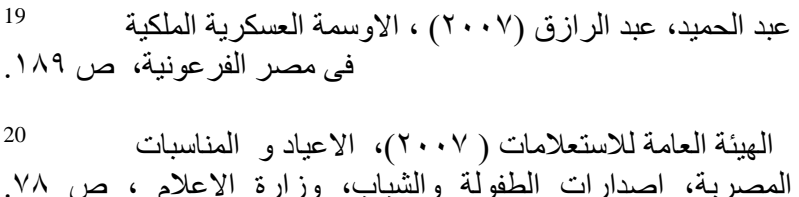

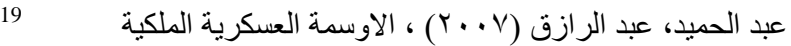

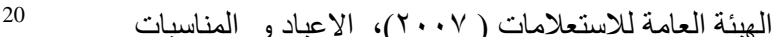

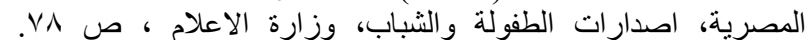


${ }^{21}$ Mcgarrity, L., \& Others (2013), Current research in Egyptology, (Proceedings of the 13 Annual Symposium, University of Birmingham), UK: Oxbow Books, p. 96.

$$
\text { رانكه، هرمان (د.ت) ، مصر والحياة المصرية فىى القديمة، ص } 7722
$$

${ }^{23}$ Mcgarrity, L., \& others (2013), Current research in Egyptology, p. 97: 99.

${ }^{24}$ Faulkner, R. (1962), A Concise Dictionary of Middle Egyptian, Oxford: Oxford University Press, p. 287.

${ }^{25}$ Manniche, L. (1991), Music and Musicians in Ancient Egypt, UK: British Museum Press, p. 75.

26 Booth, CH. (2009), Horemheb: The Forgotten pharaoh, England: Amberley Publishing, p. 53:54.

27 Booth, CH. (2009), Horemheb: The Forgotten pharaoh, p. 121.

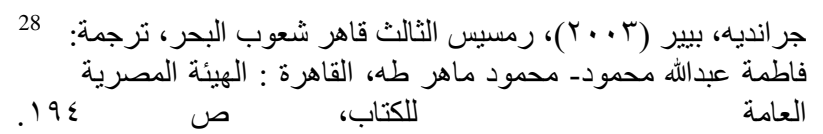

عبد الحميد، عبد الرازق (V. . . F) ، الاوسمة العسكرية الملكية فى 29

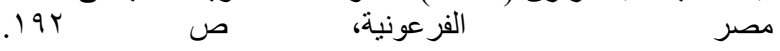

حماده، عبدالهادى (r 9 ( ) ، دليل آثار الاقصر ، ، القاهرة : مطبعة 30

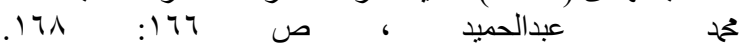

31 Porter, B., \& Moss, R. (1972), Topographical Bibliography of Ancient Egyptian Hieroglyphic Texts, Reliefs and Paintings, Vol. II, $2^{\text {nd }}$ (ed.), Oxford: Griffith Institute, Ashmolean Museum, p. 496.

${ }^{32}$ Redford, D. (2017), The Medinet Habu Records of the Foreign Wars of Ramesses III, Culture and History of the Ancient Near East Series, Leiden: Brill Academic Pub, p. 64-65.

${ }^{33}$ Kitchen, K. (1983), Ramesside Inscriptions (Historical and Biographical), Vol. V, Oxford: B.H. Blackwell LTD, p.74.

34 Gardiner, A. (1973), Egyptian Grammar "An Introduction", Oxford: Oxford University Press, p. 111.

${ }^{35}$ Faulkner, R. (1962), A Concise Dictionary of Middle Egyptian, p. 10.

36 Gardiner, A. (1973), Egyptian Grammar, p. 254.

${ }^{37}$ Edgerton, W., \& Wilson, J. (1956), Historical Records of Ramses III, vols. I- II, Chicago: Chicago University Press, p. 101.
38 Porter, B., \& Moss, R. (1972), Topographical Bibliography of Ancient Egyptian Hieroglyphic Texts, Reliefs and Paintings, p. 493.

${ }^{39}$ Nelson, H., \& Holscher, U., "Medinet Habu Reports I, Architectural Survey 1929/ 38 by Uvo Holscher II, Epigraphic survey 1928/ 31 by Harlod Nelson", OIC (10), P. 21.

${ }^{40}$ Kitchen, K. (1983), Ramesside Inscriptions (Historical and Biographical), p.51.

41 Dickson, P. (2006), Dictionary of Middle Egyptian, California, p. 257.

${ }^{42}$ Faulkner, R. (1962), A Concise Dictionary of Middle Egyptian, p. 169.

${ }^{43}$ Faulkner, R. (1962), A Concise Dictionary of Middle Egyptian, p. 139.

${ }^{44}$ Edgerton, W., \& Wilson, J. (1956), Historical Records of Ramses III, p. 102.

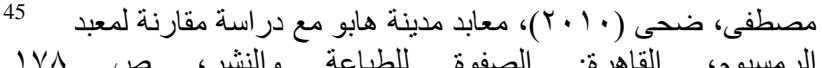

${ }^{46}$ Faulkner, R. (1962), A Concise Dictionary of Middle Egyptian, p. 148.

${ }^{47}$ Edgerton, W., \& Wilson, J. (1956), Historical Records of Ramses III, p. 69.

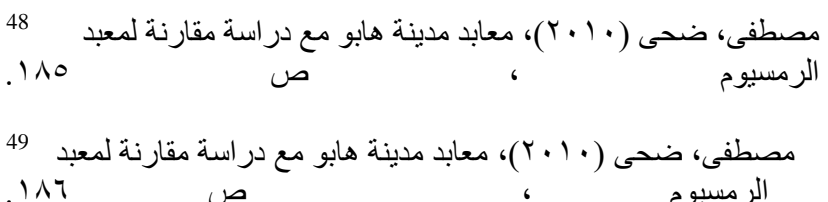

50 Kitchen, K. (1983), Ramesside Inscriptions (Historical and Biographical), p.69.

${ }^{51}$ Faulkner, R. (1962), A Concise Dictionary of Middle Egyptian, p. 43.

${ }^{52}$ Faulkner, R. (1962), A Concise Dictionary of Middle Egyptian, p. 104.

${ }^{53}$ Gardiner, A. (1973), Egyptian Grammar, p. 321.

54 Edgerton, W., \& Wilson, J. (1956), Historical Records of Ramses III, p. 98.

55 Kitchen, K. (1983), Ramesside Inscriptions (Historical and Biographical), p.70.

${ }^{56}$ Faulkner, R. (1962), A Concise Dictionary of Middle Egyptian, p. 11. 
57 Faulkner, R. (1962), A Concise Dictionary of Middle Egyptian, p. 104.

58 Edgerton, W., \& Wilson, J. (1956), Historical Records of Ramses III, p. 115. 